The Journal of British Studies

http://journals.cambridge.org/JBR

Additional services for The Journal of British Studies:

Email alerts: $\underline{\text { Click here }}$

Subscriptions: $\underline{\text { Click here }}$

Commercial reprints: Click here

Terms of use : $\underline{\text { Click here }}$

\title{
Winston Churchill's “Crazy Broadcast”: Party, Nation, and the 1945 Gestapo Speech
}

Richard Toye

The Journal of British Studies / Volume 49 / Issue 03 / July 2010, pp 655 - 680

DOI: 10.1086/652014, Published online: 21 December 2012

Link to this article: http://journals.cambridge.org/abstract_S0021937100016300

How to cite this article:

Richard Toye (2010). Winston Churchill's "Crazy Broadcast”: Party, Nation, and the 1945 Gestapo Speech. The Journal of British Studies, 49, pp 655-680 doi:10.1086/652014

Request Permissions : $\underline{\text { Click here }}$ 


\title{
Winston Churchill's “Crazy Broadcast”: Party, Nation, and the 1945 Gestapo Speech
}

\author{
Richard Toye
}

“One Empire; One Leader; One Folk!”

Is the Tory campaign master-stroke.

As a National jest,

It is one of the best,

But it's not an original joke.

(Anon., "Plagiarism," New Statesman and Nation, 30 June 1945)

o Socialist Government conducting the entire life and industry of the country could afford to allow free, sharp, or violently-worded expressions of public discontent," said Winston Churchill on 4 June 1945 in the first radio broadcast of that year's general election campaign. "They would have to fall back on some form of Gestapo, no doubt very humanely directed in the first instance." That August, nursing his wounds after his defeat at the hands of Clement Attlee's Labour Party, Churchill claimed privately to have no regrets. As Charles Eade recorded in his diary, "He said the time would come when that particular speech would be recognised as one of the greatest he had ever delivered." In fact, the speech has retained all of the notoriety that it gained

Richard Toye is an associate professor in the Department of History at the University of Exeter. He previously worked at the Universities of Manchester and Cambridge. In 2007 he won the Times Higher Education Young Academic Author of the Year Award. I am grateful to Christopher Catherwood, Paul Corthorn, David Edgerton, Ben Jackson, and Andrew Thorpe for comments and suggestions. Any errors that remain are, of course, my own responsibility.

${ }^{1}$ Broadcast of 4 June 1945. Unless otherwise stated, all of Churchill's broadcasts and speeches referred to here can be found in Robert Rhodes James, ed., Winston S. Churchill: His Complete Speeches, 1897-1963, 8 vols. (New York, 1974).

${ }^{2}$ Charles Eade, diary entry, 31 August 1945, Charles Eade Papers, Churchill Archives Centre, Cambridge $(\mathrm{CAC})$. There was a slightly different emphasis in his remarks to the editor of The Times at around the same time: "He offered no explanation [for his defeat] himself except to say ironically that it might have been different 'If I had done my broadcasts differently and if we had had a little more of your support." Donald McLachlan, In the Chair: Barrington-Ward of The Times, 1927-1948 (London, 1971), 209.

Journal of British Studies 49 (July 2010): 655-680

(C) 2010 by The North American Conference on British Studies.

All rights reserved. 0021-9371/2010/4903-0002\$10.00 
at the time of its delivery, a negative view quickly cemented by the calm but withering response made by Attlee the following day in his broadcast reply. The reaction of Leo Amery, Churchill's secretary of state for India, was a common one: "Winston jumped straight off his pedestal as world statesman to deliver a fantastical exaggerated onslaught on socialism." He described Attlee's broadcast as "a very adroit quiet reply to Winston's rodomontade." ${ }^{3}$ Historians have offered a similar verdict, almost unanimously. Churchill's official biographer, not known for his critical stance toward his subject, has described the speech's references to socialism as "hostile and injudicious." Richard Cockett, in his detailed and sympathetic account of the speech's ideological origins, concedes that it was "clumsily phrased" and lent a negative tone to the Tory campaign. ${ }^{5}$ Although the influence of a single speech on an election is necessarily hard to quantify, and although Churchill's long-standing deficit in the opinion polls suggests he would probably have lost anyway, there seems little reason to doubt the consensus view that the speech harmed his election chances. Some might say that the case it advanced was intellectually defensible, but, from the point of view of actually persuading undecided voters, it was a fiasco. It also did serious damage to his reputation.

The speech and the response to it are often seen together as a foundational moment for the postwar British political settlement, the point when calm, mildmannered, unrhetorical Attlee skewered Churchill's bombast and demonstrated his own superior qualifications as a leader in time of peace. ${ }^{6}$ The central flaw of the speech appears obvious. Between May 1940 and May 1945, Churchill himself had worked with the leaders of the Labour Party who had taken ministerial roles in his coalition government. Yet with only a slight qualification ("no doubt very humanely directed in the first instance"), he now seemed to suggest that electing them would lead to horrors equivalent to those perpetrated by the Nazis. There was an appalling credibility gap, merely accentuated by the recent revelations of the nature of concentration camps such as Belsen. However, if the standard view of the speech cannot be rejected, it is also incomplete. Although leading Labour politician Herbert Morrison immediately labeled it "Churchill's crazy broadcast," it cannot be dismissed as a mere mental lapse. ${ }^{7}$ Contextualizing the "Gestapo" comment within the speech as a whole may not vindicate Churchill, but it does cast considerable light on his electoral strategy. The broadcast needs to be seen as a failed attempt to appeal, in particular, to wavering Liberal voters. Examining it in relation to contemporary political discourse more generally is also revealing. Churchill's suggestion that his opponents' policies would lead to totalitarianism struck many people at the time as profoundly transgressive. In fact, he was deploying a trope that was very common, not least on the Labour side. The question,

\footnotetext{
${ }^{3}$ John Barnes and David Nicholson, eds., The Empire at Bay: The Leo Amery Diaries, 1929-1945 (London, 1988), 1046 (entries for 4 and 5 June 1945). The text, in fact, gives "rodomontage," a clear error.

${ }^{4}$ Martin Gilbert, Never Despair: Winston S. Churchill, 1945-1965, vol. 8 of Winston S. Churchill (London, 1988), 32.

${ }^{5}$ Richard Cockett, Thinking the Unthinkable: Think-Tanks and the Economic Counter-revolution, 1931-1983 (London, 1995), 94-96.

${ }^{6}$ See, e.g., Kenneth Harris, Attlee (London, 1982), 255-56; and Peter Hennessy, Never Again: Britain, 1945-1951 (London, 1993), 82-83.

7 “Churchill's Crazy Broadcast," Daily Herald, 5 June 1945.
} 
then, should not be why Churchill said something so outrageous. Rather, it should be why Churchill was unable to get away with saying the sort of thing that many of his opponents managed to say with impunity.

This article examines the speech, and contemporary reactions to it, from a rhetorical perspective. This is a rather unusual angle to take in the study of post1945 British politics and may require some justification. Classicists, of course, study rhetoric intensively. So do many scholars of the American political system. ${ }^{8}$ In the British context, H. C. G. Matthew's survey of developments in the 1860-1950 period stands as an important attempt to reclaim rhetoric as "an essential concomitant of representative politics" and to describe the conditions that facilitated its exercise in the great era of the mass meeting. Matthew's argument, though, is that a healthy late Victorian rhetorical culture in the end wilted in the face of new political and technological developments. ${ }^{9}$ This latter assumption is questionable, but scholars of postwar Britain appear to have accepted it. ${ }^{10}$ They do, of course, examine political language in a multitude of ways, many of them very useful, but they rarely conceive of what they are doing explicitly as rhetorical analysis. ${ }^{11}$ Indeed, those who write about political language often appear hostile to the very concept of rhetoric, taking the term, which has long held very negative connotations, to mean "just empty words," a contrast to "substance." ${ }^{2}$ Rhetoric can, of course, be abused, but there is a powerful case to be made in its defense. ${ }^{13}$ In the context of this article, "rhetoric" refers specifically to political language delivered orally, but the term is often used to include written discourse too. The best-known definition of rhetoric comes from Aristotle, who described it as "the faculty of observing in any given case the available means of persuasion," by which he meant the capacity to select from an array of potential arguments those most likely to convince the audience at hand. ${ }^{14}$ There is no evidence that Churchill was thinking consciously about classical models in 1945 , but he was certainly influenced by the Western rhetorical tradition of which Aristotle was a founding father. Churchill would certainly have agreed that the correct use of rhetoric can be a means, in an imperfect world, of trying to harmonize reason and emotion in support of desirable ends.

${ }^{8}$ A key text is Jeffrey K. Tulis, The Rhetorical Presidency (Princeton, NJ, 1987). There are numerous examples of post-1945 American political speech being subjected to rhetorical analysis-e.g., Ned O'Gorman, "Eisenhower and the American Sublime," Quarterly Journal of Speech 94, no. 1 (February 2008): 42-72.

${ }^{9}$ H. C. G. Matthew, "Rhetoric and Politics in Britain, 1860-1950," in Politics and Social Change in Modern Britain, ed. P. J. Waller (Brighton, 1987), 34-58. Another notable example of discussion of rhetoric in the run-up to 1945 is Philip Williamson, Stanley Baldwin: Conservative Leadership and National Values (Cambridge, 1999), esp. the methodological statement at 13-18.

${ }^{10}$ However, for a recent challenge to "technological determinism," see Jon Lawrence, Electing Our Masters: The Hustings in British Politics from Hogarth to Blair (Oxford, 2009), esp. 97.

${ }^{11}$ Exceptions are Jonathan Charteris-Black, Politicians and Rhetoric: The Persuasive Power of Metaphor (Basingstoke, 2005); and Ben Jackson, "The Rhetoric of Redistribution," in In Search of Social Democracy, ed. John Callaghan, Nina Fishman, Ben Jackson, and Martin McIvor (Manchester, 2009).

${ }^{12}$ Norman Fairclough, New Labour, New Language? (London and New York, 2000), vii. Other recent examples include Jamie Whyte, A Load of Blair (London, 2005); Peter Oborne, The Rise of Political Lying (London, 2005); and Steven Poole, Unspeak: Words Are Weapons (London, 2007).

${ }^{13}$ Brian Vickers, In Defence of Rhetoric (Oxford, 1998).

${ }^{14}$ Aristotle, Rhetoric, in The Complete Works of Aristotle, ed. Jonathan Barnes, 2 vols. (Princeton NJ, 1984), 2:2155. 
That ideal may seem to be the very antithesis of the unreasonable and unpersuasive Gestapo speech, but the tools of rhetorical study can still be useful when assessing what went wrong. Churchill had scaled the heights of rhetoric during the early years of World War II; now he plunged to earth with an echoing crash. His speeches, unlike those of most subsequent prime ministers, have been treated to very extensive examination. ${ }^{15}$ Even the history of particular phrases has been traced in detail. ${ }^{16}$ The focus, understandably, tends to be on his rhetorical successes, yet the picture of his oratory is hardly complete unless his failures are also considered. ${ }^{17}$ This article conceives the Gestapo broadcast as a moment of rhetorical crisis that illuminates the more profound political crisis that Churchill was facing. As Michael Kandiah and others have noted, by the end of the war the Conservative Party was up against serious difficulties. In addition to genuine (if retrospectively exaggerated) organizational problems, it appeared to lack a clear policy and leadership, with Churchill himself taking little interest in its affairs. Furthermore, the growth of progressive opinion, signaled by by-election results and the popular reception of the Beveridge Report on social services, opened ideological divisions among Conservatives. The Tory Reform Group's sympathy toward collectivist policies was not shared by those skeptical of the growth of taxation and state control. ${ }^{18}$ Churchill was not aware of how much a challenge he faced in seeking reelection. Opinion polls predicted that he would lose, but he appears not to have known this until after his defeat, and few other politicians took the surveys seriously either. But although he expected to win, he had an understandable sense of foreboding about the postwar era, and his sense of unease about his electoral chances grew throughout the campaign. ${ }^{19}$ Again, we need to invert the normal order of priorities. Rather than asking what led Churchill to create a predicament for himself through unwise use of language, we need to ask what it was about his political predicament that led him to say something unwise. This is not to say that the Gestapo speech did not deepen his existing troubles or that it did not contribute to his loss of the election. However, it is to say that it was not merely a temporary aberration of Churchill's but was more broadly symbolic of his and his party's loss of political bearings. As his doctor observed after listening to the broadcast, "He has a feeling that he is back in the thirties, alone in the world, speaking a foreign tongue. ${ }^{20}$

\footnotetext{
${ }^{15}$ It is mainly his World War II speeches that have been examined, although his 1946 "iron curtain" address has also received considerable attention. Churchill, then, forms only a partial exception to the general neglect of post-1945 British political rhetoric.

${ }^{16}$ For example, Manfred Weidhorn, "Churchill the Phrase Forger," Quarterly Journal of Speech 58, no. 2 (April 1972): 161-74; David Cannadine, In Churchill's Shadow: Confronting the Past in Modern Britain (London, 2003), chap. 4; Patrick Wright, Iron Curtain: From Stage to Cold War (Oxford, 2007); and John Lukacs, Blood, Toil, Tears and Sweat: The Dire Warning (New York, 2008).

${ }^{17}$ For the importance of studying weak rhetoric, see Todd S. Frobish, ed., Crises in American Oratory: A History of Rhetorical Inadequacy (Dubuque, IA, 2007).

${ }^{18}$ Michael David Kandiah, "The Conservative Party and the 1945 General Election," Contemporary Record 9, no. 1 (Summer 1995): 22-47. See also Andrew Thorpe, Parties at War: Political Organization in Second World War Britain (Oxford, 2009).

${ }^{19}$ Lord Moran, Winston Churchill: The Struggle for Survival, 1940-1965 (London, 1968), 187, 254, $278,309$.

${ }^{20}$ Ibid., 253.
} 
The speech needs to be understood in terms of Churchill's desire to present himself as the ideological heir of the near-defunct Liberal Party. Although he had begun his political career as a Conservative, he switched to the Liberal Party in 1904. As a minister under H. H. Asquith before World War I, he was closely associated with significant social reforms, such as the introduction of National Insurance, and his reputation was closely bound up with that of his radical colleague, David Lloyd George. ${ }^{21}$ After the fall of the Lloyd George coalition in 1922, Churchill gravitated back toward the Conservative Party and in 1924 was appointed by the Conservative prime minister Stanley Baldwin as Chancellor of the Exchequer. As Martin Daunton has argued, in this role, Churchill "consciously seized the mantle of David Lloyd George" and aimed "to appropriate the ideology of 'new Liberalism' which had, to a large extent, migrated into the Labour party."22 (The inclusion of Churchill in the cabinet also helped reinforce Baldwin's own claim to represent "national" as opposed to sectional values. $)^{23}$ It is notable that, when discussing his own Liberal heritage in these and later years, Churchill generally talked most about social policy, Lloyd George, and the New Liberalism of the pre-1914 period. However, when attacking Lloyd George's own ambitious plans to conquer unemployment during the 1929 election, Churchill accused the Liberal Party of abandoning the canons of Gladstonian finance, which, he implied, were now upheld by the Tories.

During Churchill's 1930s wilderness years, the Liberal aspect of his identity became dormant again, in spite of his efforts to collaborate with individual Liberals in his fight against appeasement. It remained so during most of World War II. He was good friends with the Liberal leader Archibald Sinclair, who was his secretary of state for air, but he did have doubts about Sinclair's leadership of the party and felt that the Liberal party was overrepresented in the government in relation to the small numbers it had in the Commons. ${ }^{24}$ The far more vocal and arguably more authentic voice of wartime Liberalism was Sir William Beveridge. Churchill viewed him as "an awful windbag and a dreamer." 25 This hostility, however, derived substantially from the fact that Churchill viewed discussion of postwar social reconstruction-and the parliamentary difficulties that the Beveridge Report caused his government-as a distraction from the war effort. He was not opposed to the extension of welfare provision per se, and as the 1945 election approached, Churchill rediscovered himself as a social reformer and as an heir to the Liberal tradition. ${ }^{26}$ This was in line with the Conservative social reform tradition and with

${ }^{21}$ Richard Toye, Lloyd George and Churchill: Rivals for Greatness (London, 2007).

${ }^{22}$ Martin Daunton, Just Taxes: The Politics of Taxation in Britain, 1914-1979 (Cambridge, 2002), 135.

${ }^{23}$ See Williamson, Stanley Baldwin, 353, for Baldwin's status "as a sort of honorary Liberal."

${ }^{24}$ Ian Hunter, ed., Winston and Archie: The Collected Correspondence of Winston Churchill and Archibald Sinclair, 1915-1960 (London, 2005), 338, 412.

${ }^{25}$ G. S. Harvie-Watt, Most of My Life (1980), 117, quoted in Kevin Jefferys, The Churchill Coalition and Wartime Politics, 1940-1945 (Manchester, 1991), 119.

${ }^{26}$ Richard Toye, "I am a Liberal as much as a Tory': Winston Churchill and the Memory of 1906," Journal of Liberal History, no. 54 (Spring 2007): 38-45. See also Malcolm Baines, "The Liberal Party and the 1945 General Election," Contemporary Record 9, no. I (Summer 1995): 48-61. 
the party's efforts, both before and after 1945, to appeal to Liberal opinion and to ally itself with elements of the collapsing Liberal Party as they sheared off. ${ }^{27}$

Churchill's efforts must also be seen as part of his bid to present himself as a "national," nonpartisan politician. This too was in line with previous leaders' strategies. There was an irony in this. When the National Government was formed in 1931, Churchill—denied ministerial office—was privately disparaging although supportive of it in public. His high-profile campaigns against reform in India and in favor of rearmament were seen by many, not without reason, as efforts to destabilize it. A famous entry in the index of his Second World War memoirs accused Baldwin, the government's moving spirit, of putting party before country. ${ }^{28}$ Churchill's own government of 1940 , which stretched, as he boasted, "from Lord Lloyd of Dolobran on the Right to Miss [Ellen] Wilkinson on the Left," had a much more plausible claim to being genuinely nonpartisan. ${ }^{29}$ However, he jeopardized his own above-party status by accepting the leadership of the Conservative Party on the retirement of Neville Chamberlain. After VE-Day, the Labour Party and the majority of Liberal ministers withdrew from the coalition, yet Churchill was determined to hang on to the "National" label nonetheless. The irony lay in the fact that Churchill was linking himself to a brand that had paid great dividends for Baldwin and Chamberlain. But because of the perceived failures of the original National Government, it was a brand that was heavily devalued. Churchill would struggle to overcome this, even though his credentials as a national leader were apparently exceptional.

In March 1945, when it was already clear that Labour and the Liberals would probably leave the coalition once victory in Europe was won, Churchill addressed the Conservative Party conference in London. He declared: "Should it fall to me, as it may do, to form a Government before the election, I shall seek the aid not only of Conservatives but of men of good will of any party and no party who are willing to serve and thus invest our Administration with a national character." ${ }^{30}$ After Lord Croft (formerly Henry Page Croft, MP) wrote to congratulate him on his speech, Churchill replied, explaining his thinking:

I do not intend a National Government founded on the official agreement of Labour and Liberals, unless of course we are denied an effective working majority. But both before and after the Election, I hope to have the help of eminent and capable men who can do their various heavy jobs to the highest public advantage. As an old political campaigner, you will realise the advantage of having "socialists $v$. the rest" rather than "Tories v. the rest". I imagine this is even more true in an election where there must be an enormous vote unattached to any particular Party. ${ }^{31}$

When the coalition broke up in May, Churchill created a new Caretaker Government. Inevitably, it was dominated by Conservatives. However, he also went to

${ }^{27}$ E. H. H. Green, Ideologies of Conservatism (Oxford, 2004), 253.

${ }^{28}$ The entry read, "Baldwin, Rt. Hon Stanley . . . confesses putting party before country." Churchill did not write the entry himself, but it represented his view. David Reynolds, In Command of History: Churchill Fighting and Writing the Second World War (London, 2004), 94.

${ }^{29}$ As recalled by Harold Macmillan, quoted in Betty D. Vernon, Ellen Wilkinson (London, 1982), 184.

${ }^{30}$ Speech of 15 March 1945.

${ }^{31}$ Winston Churchill to Lord Croft, 17 March 1945, Croft Papers, CAC, CRFT 1/8. 
considerable lengths to recruit non-Tories. One of these was the sixth earl of Rosebery, son of Lord Rosebery, the former Liberal prime minister, who became secretary of state for Scotland. Another was Lloyd George's son Gwilym, who had declared that he meant to fight the next election "as a Liberal candidate supporting the National Government. ${ }^{32}$ Leslie Hore-Belisha, appointed minister of National Insurance, had originally been elected as a National Liberal but had become an independent in 1942. He was to fight in the coming election (and lose) as a National candidate. There were further similar examples. There were no Labour representatives in his government; the vestigial National Labour Party was dissolved in June 1945. However, in the Gestapo broadcast and in the election campaign generally, Churchill would make much play with the government's supposed "national" status. Strikingly, his election manifesto made no mention of the Conservatives or of any other political party. ${ }^{33}$

It is no surprise, then, that The Times headlined its report of the Gestapo speech "Vote National, Not Party." ${ }^{34}$ There was, however, a powerful disjuncture between Churchill's claim that he and his colleagues transcended party and the Gestapo comment itself, which sounded like a partisan political insult. Churchill had a long history of engaging in such gibes. In 1920 he had described the Labour Party as "simpletons" who worshipped Russia and were "unfit to govern the country." They stood, he said, "for a system of society where the whole business of the country would have to be run by Government officials, under the direction of 'political bosses." "35 During the 1935 election campaign, he claimed that "when the air raids were on in the great war you could not get into the Tubes because of Socialists scuttling into them like sewer rats." ${ }^{36}$ In 1945 it was easy for Labour, therefore, to portray him as reverting to type.

Churchill was, however, by no means the only politician to use "Gestapo" as an insult. (He himself had been described as "Kaiser-like" at the Trades Union Congress in 1926. $)^{37}$ The term had long since entered the English language. The Gestapo-a contraction of "Geheime Staatspolizei" - was founded in April 1933 and received its first mention in The Times on 13 October of that year. It received over a thousand further mentions in the paper prior to Churchill's 1945 broadcast, the vast majority of them after 1939. At the outbreak of war, Bob Boothby, MP, had written to Churchill deploring a list of government appointments "issued by Margesson's 'Gestapo," the reference being to David Margesson, government chief whip. ${ }^{38}$ By November 1940, Minister of Works John Reith and Labour War Cabinet member Arthur Greenwood were referring to the prime minister's Statistical Branch, with its habit of interference, as "Churchill's Gestapo." 39 These,

\footnotetext{
32 "Major Lloyd-George's Future," The Times, 20 March 1945.

${ }^{33}$ Churchill to Ralph Assheton, 11 June 1945, Churchill Papers, CAC, CHAR 2/554, fol. 14.

${ }^{34}$ There were also smaller subheadings: "Prime Minister's Broadcast Attack on Socialism" and "Policy Abhorrent to British Ideas of Freedom." The Times, 5 June 1945.

${ }^{35}$ Speech of 14 February 1920.

36 "Socialists Ran like Rats," Daily Express, 7 November 1935.

${ }^{37}$ Report of Proceedings at the 58th Annual Trades Union Congress (London, 1926), 346. The speaker was Ben Turner.

${ }^{38}$ Robert Boothby to Churchill, 7 September 1939, in The Churchill War Papers, ed. Martin Gilbert, 3 vols. (New York and London, 1993-2000), 1:48.

${ }^{39}$ Charles Stuart, ed., The Reith Diaries (London, 1975), 271.
} 
of course, were only private remarks. In December 1944, though, Greenwood (who had by that point left the government) suggested in parliamentary debate that British forces in Greece acting against the left-wing resistance movement were being "driven into the position of a sort of Gestapo." ${ }^{40}$

More significant was the long-standing Labour critique of Conservatism as a kind of cryptofascism. In this analysis, the pretension to "national" values was particularly suspicious, and the critique extended to the Tory Party's allies. In 1937, Attlee attacked the philosophy of Ramsay MacDonald, Labour's own former leader, who had headed the National Government from 1931 to 1935: "MacDonaldism is, in fact, essentially Fascist. MacDonald himself uses the same phrases that may be found in the mouth of Hitler and Mussolini. He constantly draws a distinction between party and national interests, the theory being that there is really some ideal course to be followed for the good of the country and that party politics are deflections caused by mere factiousness." ${ }^{21}$ This is consistent with Richard Overy's recent observation that, during the period in question, the word "fascism" was "increasingly used in a general sense to describe all political and social tendencies which threatened to undermine political liberty and human rights, either abroad or at home." Overy also observes that "Hitler became the reference point for so much of the discussion of crisis in the 1930s, a lightning conductor for anxieties or expectations which were as much domestic in origin as they were occasioned by German realities." 42 This continued into the war period. A number of pamphlets that attacked the Tories claimed that there was a symbiosis between Conservatism and fascism. Tom Wintringham (a former communist and founding member of the Common Wealth Party) published Your MP in 1944. This pamphlet sold over 200,000 copies. ${ }^{43}$ Wintringham wrote of how "inevitably Conservatism turned towards Fascism, based hopes on it, accepted it as an ally-until its madness broke into world war. And even then the Tories could not see it for what it was." Aneurin Bevan, MP, wrote in the same year that "the Tory is a potential Fascist element in the community." 45 The Conservatives' 1930s foreign policy record could be invoked in support of such arguments. The Labour Party's 1945 Speaker's Handbook explained that "the Tories' real policy all through was to let Fascist aggressors get away with their crimes because they wanted to keep Fascism and its oriental ally Japanese militarism strong enough to hold down the working class in Europe and to bolster up Imperialism in Asia and Africa." Conservatives had been fully aware of fascist methods, including the concentration camps, which had "flourished all through the years the Tories were coddling and appeasing their friends Hitler and Mussolini." 46

The Handbook was published in June, the concentration camps having been

\footnotetext{
${ }^{40}$ Arthur Greenwood, Speech to the House of Commons, 20 December 1944, Parliamentary Debates, Commons, 5th ser., vol. 406 (1944-45), col. 1862.

${ }^{41}$ C. R. Attlee, The Labour Party in Perspective (London, 1937), 60.

${ }^{42}$ Richard Overy, The Morbid Age: Britain between the Wars (London, 2009), chap. 7, 274, 300.

${ }^{43}$ Sheila Hodges, Gollancz: The Story of a Publishing House, 1928-1978 (London, 1978), 154.

${ }^{44}$ Gracchus [Tom Wintringham], Your MP (London, 1944), 81.

${ }^{45}$ Celticus [Aneurin Bevan], Why Not Trust the Tories? (London, 1944), 84.

${ }^{46}$ The Labour Party, Speaker's Handbook, 1945 (London, 1945), 179. See also Scott Kelly, "The Ghost of Neville Chamberlain': Guilty Men and the 1945 Election," Conservative History Journal, no. 5 (Autumn 2005): 18-24.
} 
liberated between 11 April (Buchenwald) and 8 May (Mauthausen). It was the liberation of Belsen on 15 April that made the strongest impression on the British public mind. The conditions there, memorably reported by Richard Dimbleby among others, were unspeakably horrific and had led to appalling numbers of deaths through hunger, disease, and neglect; but, it should be noted, it was not actually an extermination camp in the sense of there being a deliberate policy of mass killing. The fact of the Jewish Holocaust had been reported in 1944, but, in the absence of photographs and eyewitness testimony of the kind that now emerged from Belsen, it did not sear itself into the British consciousness. Moreover, the liberation of the camps was not understood at the time in the context of the "Final Solution." Left-wingers tended to view the camps in light of what had been known about them in the 1930s - that is, that they had been used to repress Social Democrats and other political opponents of the Nazis, even as the Conservative policy of appeasement continued. In this context, Churchill's Gestapo comment was particularly inopportune. At this moment, socialists could be far more persuasively portrayed as the likely victims of Nazi-style political terror than as its likely perpetrators. As Joanne Reilly has suggested, the news from the camps played into Labour's hands. ${ }^{47}$

Labour narratives did not, of course, go uncontested. Conservatives liked to point out that the Nazis called themselves National Socialists. Basil Webb's book The House Divided (1945) was an attempted rebuttal of Your MP and included a section on "Left Roads to Fascism." Webb pointed to the record of Stafford Cripps's Socialist League, which had acted as a left-wing pressure group within the Labour Party in the 1930s before being forcibly wound up. He echoed earlier criticisms that Cripps's plans for radical socialist transformation required dictatorial methods: "The policy of the Socialist League meant dictatorship. But the threat has not passed. The Socialist League is dissolved, it is true. But the hopes of the old Socialist Leaguers still burn in many Left-Wing bosoms. There are still many who cherish the spirit of National Socialism which the League embodied. National Socialism - and all that it implies-is still only too great a danger." ${ }^{48}$ A number of Conservatives, following Churchill's own lead in the Gestapo speech but also deploying this established argument, would make claims like this during the course of the election campaign.

Churchill himself was not immune from the left-wing charge of fascist sympathies. In 1933, Cripps told the moderate Labour politician Hugh Dalton of his belief that Churchill would defeat the National Government on the issue of India before forming an administration that would "introduce fascist measures" and put an end to general elections. Dalton thought that Cripps was talking nonsense. ${ }^{49}$ Far-left critics of Churchill, though, were able to point to various hostages to fortune that he had given during the interwar years, especially his praise of Mussolini. In 1943, the New Leader, a small-circulation weekly published by the Independent Labour Party, quoted an example of this dating from 1927. (When H. G. Wells wrote to Downing Street urging that the story be contradicted, in

\footnotetext{
${ }^{47}$ This paragraph draws on Joanne Reilly, Belsen: The Liberation of a Concentration Camp (London, 1998), esp. chap. 2.

${ }^{48}$ Basil Webb, The House Divided (London, 1945), 45.

${ }^{49}$ Hugh Dalton, The Fateful Years: Memoirs, 1931-1945 (London, 1957), 41-42.
} 
the belief that Churchill had never said anything of the kind, a private secretary replied, obligingly enclosing a cutting from The Times that showed that Churchill had indeed spoken of being "charmed" by Mussolini's "gentle and simple bearing" and had said that Italian fascism had "rendered a service to the whole world.") ${ }^{50}$ The New Leader would not be alone in developing such themes during the general election. The Daily Herald, the Labour movement's official paper, ran the headline "A Vote for Churchill Is a Vote for Franco," prefaced, in smaller letters, by "This Is the Election Cry the Tory Organisers Fear." ${ }^{\prime 1}$

It was not only extreme left-wingers who suggested that Churchill's political techniques were profoundly unsavory. In 1934, Churchill claimed that ministers had abused parliamentary privilege by interfering with witnesses to the Select Committee on Indian Reform. The complaint was rejected by the Committee of Privileges. In the debate that followed, Sir John Simon, the foreign secretary, said that Churchill's "protests that all this had been done out of a passionate affection for the purity of the law of Parliament really carry as much conviction as the protests of Sir Oswald Mosley [leader of the British Union of Fascists] that the brutalities of his uniformed bullies are all explained by a passionate attachment to free speech." ${ }^{52}$ In May 1945, Attlee publicly rejected the suggestion that the coalition might be prolonged. Churchill had coupled that idea with a proposal to hold a referendum on whether the life of the current parliament should be prolonged. "I could not consent to the introduction into our national life of a device so alien to all our traditions as the referendum, which has only too often been the instrument of Nazism and Fascism," Attlee wrote. He added, "Hitler's practices in the field of referenda and plebiscites can hardly have endeared these expedients to the British heart." ${ }^{53}$ Sir Alan Lascelles, the king's private secretary, wrote in his diary that "Attlee was guilty of a great breach of taste (and of tactics) in suggesting . . . that Winston's suggestion of a referendum savoured of Hitlerite methods." ${ }^{54}$ It may have been a breach of taste, but there is no reason to think that the tactic backfired.

Thus, Churchill made his Gestapo charge at a time when other figures in both main parties had been flinging similar insults and allegations around for some while. In no case did any of these other instances become notorious or create a media storm. This immediate context is important; in accounting for the Gestapo speech, it is possible to overemphasize intellectual influences on Churchill at the expense of other, cruder elements of contemporary discourse. Nevertheless, those intellectual influences may have been important, and it is to them that we now turn.

In 1935, F. A. Hayek, an Austrian émigré economist based at the London School of Economics, published Collectivist Economic Planning. This edited collection was a pioneering work on the theory of planning that cast doubt on its practicality.

\footnotetext{
${ }^{50}$ H. G. Wells to "The Private Secretary of Mr. Winston Churchill," 29 July 1943, Wells Papers, University of Illinois, WC-37-2; J. H. Peck to Wells, 14 August 1943, enclosing "Mr. Churchill on Fascism," The Times, 21 January 1927, Wells Papers, C-238-25.

${ }^{51}$ Daily Herald, 18 June 1945.

52 "House of Commons," The Times, 14 June 1934.

53 "July Election Nearer," The Times, 22 May 1945.

${ }^{54}$ Duff Hart-Davis, ed., King's Counsellor: Abdication and War; The Diaries of Sir Alan Lascelles (London, 2006), 327.
} 
Hayek's colleague Lionel Robbins sent a copy to Churchill, recommending the section dealing with the results of economic planning in Russia, but there is no evidence that Churchill read it. ${ }^{55}$ Subsequently, in the face of new work on planning theory, Hayek stopped arguing that planning was a technical impossibility and instead claimed that it could not be implemented successfully without highly undesirable political and social consequences. In The Road to Serfdom (1944), Hayek argued that political and personal freedom was contingent on freedom in economic affairs, that there was no third course between an economic system based on free enterprise and one based on totalitarianism, and that attempts by the state to plan economic life would tend to the destruction of liberty. The book was a successful work of popularization, but its ideas were not especially original. ${ }^{56}$ Indeed, elements of its argument had been present in Conservative Party propaganda for some time. For example, a 1929 poster warned voters that "Socialism would mean inspectors all round" and advised them that "If you want to call your soul your own, vote Conservative. ${ }^{257}$

Hayek later wrote ruefully that "I am afraid there can be little doubt that Winston Churchill's somewhat unfortunately phrased Gestapo speech was written under the influence of The Road to Serfdom." ${ }^{\text {8 }}$ During 1944, he himself made two efforts to get the book into Churchill's hands. In March he sent Churchill a copy. ${ }^{59}$ In October, he lunched with the Conservative MP Waldron Smithers and asked him "most earnestly" to send Churchill a (further) copy. This Smithers did, suggesting that the prime minister could get the book's gist from the introduction and noting the "tremendous interest" it had aroused in the country. ${ }^{60}$ Again, however, it is unclear whether Churchill actually read Hayek's book himself. Cockett suggests, plausibly, that Churchill may have been influenced by Hayek secondhand via Conservative Party Chairman Ralph Assheton. Assheton was so impressed by The Road to Serfdom that he bought fifty copies and sent them to colleagues and also to Attlee and Herbert Morrison. In April 1945, Assheton made a speech that not only had a clear Hayekian tinge but also associated Labour's policies with Nazi dictatorship, via a xenophobic take on Marx. "We in this country have been fighting against totalitarianism in Germany and we do not wish to adopt as our creed the German-made doctrines of Karl Marx," he said. "I do not think that most of those who toy with Socialist theories and doctrines in this country sufficiently realise that Socialism . . . inevitably leads to a totalitarian State." He sent his text in advance to Churchill, who thought it "very good."

It is certainly possible that Assheton's speech had an impact on Churchill. After the Gestapo broadcast, Emrys Hughes, editor of the socialist weekly Forward,

\footnotetext{
${ }^{55}$ Lionel Robbins to Churchill, 15 February 1935, Churchill Papers, CHAR 2/234, fol. 65.

${ }^{56}$ Cockett, Thinking the Unthinkable, 79

${ }^{57}$ The Bodleian Library, Oxford, has a collection of Conservative Party posters, including this one, available online at http://www.bodley.ox.ac.uk/dept/scwmss/cpa/.

${ }^{58}$ F. A. Hayek to Paul Addison, 13 April 1980, quoted in Paul Addison, Churchill on the Home Front, 1900-1955 (London, 1992), 383.

${ }^{59}$ Hayek to "The Principal Private Secretary to the Prime Minister," 15 March 1944, Churchill Papers, CHAR 2/253, fol. 17.

${ }^{60}$ Waldron Smithers to Churchill, 9 October 1944, Churchill Papers, CHAR 2/497, fol. 31.

${ }^{61}$ Cockett, Thinking the Unthinkable, 92-93.
} 
noted that Assheton had started a trend of linking Labour with totalitarianism. ${ }^{62}$ It is worth remembering though that Churchill, in his 1920 speech quoted above, had previously attacked socialism as leading to authoritarian rule. It is also worth noting that, as Ben Jackson has argued, The Road to Serfdom should not be seen as simply a first installment of the rise of the Thatcherite New Right. Hayek (who saw himself as a Liberal rather than a Conservative) objected to full-scale centrally planned socialism, not to all forms of welfare legislation. ${ }^{63}$ If this is understood, it is easier to see how Churchill could make use of Hayekian ideas in the Gestapo speech while simultaneously championing social reform. ${ }^{64}$ The speech was to include appeals to two competing strains of Liberalism that, to him, did not necessarily appear incompatible. He was not, in fact, the most extreme person on the National side. Rowland Hunt, general secretary of the National Liberals, argued not long before Churchill's broadcast that the proposals of Beveridge were contrary to Liberalism and "if adopted would be Hitler's last triumph, for Britain would then become a completely totalitarian state." ${ }^{65}$

Churchill wrote the speech at Chequers over the weekend of 2-3 June. Although many people, when they heard it, suspected the involvement of his cronies Lord Beaverbrook and Brendan Bracken, MP, it was his own work. ${ }^{66}$ There is no surviving account of how Churchill came to light upon the Gestapo phrase. According to his youngest daughter, though, his wife warned him not to use it: "Clementine, to whom he had shown the script of his broadcast, spotted this unfortunate sentence at once, and she had begged Winston to delete the odious and invidious reference to the Gestapo. But he would not heed her." ${ }^{67}$ After the war he expressed a note of private regret-while defending the speech as a whole - that he had had to refer to the Gestapo rather than to the Soviet NKVD, the forerunner of the $\mathrm{KGB}^{68}{ }^{6}$ At the time that he made the broadcast, he was already highly concerned

${ }^{62}$ Emrys Hughes, “'Gestapo Will Get You,’ Forward, 9 June 1945.

${ }^{63}$ Ben Jackson, "At the Origins of Neo-liberalism: The Free Economy and the Strong State, c. 1930-1947," Historical Journal 53 (2010): 129-51. For Hayek's belief in a "minimum income," see F. A. Hayek, The Road to Serfdom (1944; repr., London, 1962), 89.

${ }^{64}$ Harriet Jones has noted the apparent tensions in the Conservative election message, suggesting that the manifesto had a "basic lack of consistency represented in the simultaneous advocacy of social reform and financial orthodoxy" (Harriet Jones, "The Conservative Party and the Welfare State, 1942-1955" [PhD thesis, University of London, 1992], 108-9, quoted in Kandiah, "Conservative Party," 33).

${ }^{65}$ New Horizon, April 1945, quoted in David Dutton, Liberals in Schism: A History of the National Liberal Party (London, 2008), 142. Similar arguments, directed at Labour's nationalization plans, were made by some grassroots Conservatives. See Thorpe, Parties at War, 176.

${ }^{66}$ John Colville, The Fringes of Power: Downing Street Diaries, 1939-1955 (London, 1985), 606. Colville told Lascelles that "the only share the Beaver had had in it was the deletion of a tribute to Ernie Bevin," the trade unionist and former minister of labour. Nevertheless, the speech did make a mildly positive reference to Bevin's demobilization scheme. See Hart-Davis, King's Counsellor, 331.

${ }^{67}$ Mary Soames, Clementine Churchill (Harmondsworth, 1981), 545.

${ }^{68}$ Cockett, Thinking the Unthinkable, 94. However, Churchill was not completely consistent in his defense of the speech. When at last introduced to Hayek after the war, Churchill told him that his arguments in The Road to Serfdom were right but that "it would never happen in England," which of course contradicted his own argument in 1945. Hayek to Addison, 13 April 1980, quoted in Addison, Churchill on the Home Front, 383. 
about Soviet geopolitical ambitions, first using the phrase "iron curtain" in correspondence with President Truman on 12 May. (He believed, however, that a personal meeting with Stalin might help achieve an East-West understanding. $)^{69}$ He was, of course, constrained from offering public criticism by the fact that Britain and the Soviet Union were still allies. In the domestic context, moreover, it must have seemed doubtful that traditional "red scare" tactics could be as effective against Labour as they had been in 1924 and 1931, given the Soviet Union's recently found popularity with much of the British public, which reflected admiration for the efforts of the Red Army. Nonetheless, his actual choice of words implicitly linked Stalinism with Nazism, because he was arguing that all socialist systems would require a Gestapo. Therefore, his speech can be seen as part of the process by which British reactions to prewar and wartime fascism and postwar communism became fused, with the Soviet Union replacing Germany as the threat to "civilization" in the early stages of the cold war. ${ }^{70}$

On Monday, 4 June, Churchill delivered the broadcast in the study at Chequers. It lasted twenty-one minutes and fifteen seconds. ${ }^{71}$ His private secretary, John Colville, observed that "he was speaking against the clock which made him hurry unduly." 72 Churchill devoted his first few paragraphs to his regret at the breakup of the coalition. "I know that many of my Labour colleagues would have been glad to carry on," he said. He did concede that political parties had always played a great role in British affairs: "Party ties have been considered honourable bonds, and no one could doubt that when the German war was over and the immediate danger to this country, which had led to the Coalition, had ceased, conflicting loyalties would arise." But he immediately went on to suggest that being bound by such ties was, in the current circumstances, dishonorable: "Our Socialist and Liberal friends felt themselves forced, therefore, to put party before country. They have departed and we have been left to carry the nation's burden." Churchill could certainly have relied on most of his listeners to accept his unstated axiom that it was wrong to put party before country. In his reference to "the nation's burden," there was an echo of the charge leveled against the Labour Party in 1931 that it had run away from its responsibilities during the financial crisis that triggered the creation of the National Government. It is, of course, common for politicians to describe office as a burden even when they themselves are not in the least inclined to give it up.

Churchill then expounded his claim that his Caretaker administration was a National Government. He said, "I claim the support of all throughout the country who sincerely put the nation first in their thoughts." This was an ambiguous remark. Was he claiming he already had it, or was he merely claiming it in the sense of asking for it? At any rate, it carried the strong implication that those who did not support him were not sincerely putting the nation first. He himself, he

\footnotetext{
${ }^{69}$ Churchill to Harry S. Truman, 12 May 1945, in U.S. Department of State, Foreign Relations of the United States: Diplomatic Papers; The Conference of Berlin (The Potsdam Conference), 1945, 2 vols. (Washington, DC, 1960), 1:8-9.

${ }^{70}$ Overy, Morbid Age, chap. 7, 265-313; Ann Deighton, The Impossible Peace: Britain, the Division of Germany and the Origins of the Cold War (Oxford, 1993), 221.

${ }^{71}$ Asa Briggs, The History of Broadcasting in the United Kingdom, vol. 4, Sound and Vision (Oxford, 1979), 627 n. 4.

${ }^{72}$ Colville, Fringes of Power, 606.
} 
said, would stand as a "Conservative and National" candidate: "Others may choose to call themselves National or National Liberal, and those who give us their support should vote National rather than Party on polling day." Perhaps Churchill felt he was on weak ground, because he then spent several more sentences arguing that the government really was a National one. At the least, he was not able to take it for granted that his claim would be accepted automatically. This section of the broadcast was largely concerned with making an ethical appeal-that is to say, an appeal based on the ethos, or character, of the speaker. Churchill presented himself and his colleagues as men who, by selflessly shouldering the burden of office, were already putting the national interest first. They could therefore be trusted to do so in the future.

Next, he turned to the Liberals: "Particularly do I regret the conduct of the Liberal Party. Between us and the orthodox Socialists there is a great doctrinal gulf, which yawns and gapes. . . . There is no such gulf between the Conservative and National Government I have formed and the Liberals. There is scarcely a Liberal sentiment which animated the great Liberal leaders of the past which we do not inherit and defend." In order to justify this point, he referred both to his government's "championship of freedom" and to the Four-Year Plan for postwar reconstruction that he had outlined in March 1943. This included proposals for a National Health Service and for cradle-to-grave national insurance. However, Churchill did not now reiterate any of these details, appearing to assume that his audience was already familiar with the plan. He asserted that the program of social reform it contained was "so massive, so warm, so adventurous" that Gladstone would have felt it was going too far. "But we still have a Rosebery and a LloydGeorge to carry forward the flags of their fathers." Rather surprisingly, although he mentioned these family connections of members of his government, he failed to comment on his own concrete record of reform or his past association with Lloyd George.

Having explained how much in common Liberals had with his government, Churchill faced the tricky task of explaining why the Liberal Party had "spurned" him and his colleagues by withdrawing from the coalition. (During the war he had pressed without success for Liberal reunion and must have been aware that Sinclair's independent Liberals had been divided on whether to continue the coalition.) His explanation verged on the comic: "I am sorry to tell you that they have yielded to the tactical temptation, natural to politicians, to acquire more seats in the House of Commons, if they can, at all costs." The Liberals, it seemed, had left office out sheer self-interest in spite of agreeing with the Conservatives on every significant ideological point! After attacking the Liberal leaders, Churchill attempted to win over their supporters. He appeared to assume that Liberals were, in fact, likely to vote Labour. He appealed to them to ask themselves whether his government "has not more claim on their ancestral loyalties than has a Socialist administration, whose principles are the absolute denial of traditional Liberalism." It was here that he segued into his philosophical denunciation of socialism, which he combined with an assault on Labour's Liberal credentials: "My friends, I must tell you that a Socialist policy is abhorrent to the British ideas of freedom. Although it is now put forward in the main by people who have a good grounding in the Liberalism and Radicalism of the early part of this century, there can be no doubt that Socialism is inseparably interwoven with Totalitarianism and the abject worship 
of the State." At this point, the language of the speech became increasingly vivid, even lurid. Through such language, although ostensibly appealing to logos (reason), he also made an appeal to pathos (emotion). He argued that socialism challenged not only property but all forms of liberty and, to illustrate this, spoke of socialists' "hunger for controls of every kind, as if these were delectable foods instead of war-time inflictions and monstrosities." Under socialism, he said, all would be forced to obey the state in every act of life. He then talked about the state as though it were a person. It would be "the arch-employer, the arch-planner, the arch-administrator and ruler, and the arch-caucus-boss." He then shifted his imagery, invoking the pathetic spectacle of "an ordinary citizen or subject of the King" contending with "this formidable machine." Later still in the speech, the state became "this mighty organism."

A complete socialist state, he continued, would be unable to tolerate opposition. He used some rolling phrases of the kind for which he was well known, linking patriotic sentiment with his abstract argument: "Here in old England, in Great Britain, of which old England forms no inconspicuous part, in this glorious Island, the cradle and citadel of free democracy throughout the world, we do not like to be regimented and ordered about and have every action of our lives prescribed for us." Socialism, moreover, was an attack "upon the right of the ordinary man or woman to breathe freely without having a harsh, clumsy, tyrannical hand clapped across their mouths and nostrils." Citing proposals made by both Morrison and Cripps to increase the efficiency of Parliament by curtailing debate on the details of policy, he claimed that "a Free Parliament is odious to the Socialist doctrinaire." He then went further and said that "no Socialist system can be established without a political police." He acknowledged that many advocates of socialism would be "horrified" at this suggestion. "That is because they are short-sighted, that is because they do not see where their theories are leading them."

Then came the crucial passage:

No Socialist Government conducting the entire life and industry of the country could afford to allow free, sharp, or violently worded expressions of public discontent. They would have to fall back on some form of Gestapo, no doubt very humanely directed in the first instance. And this would nip opinion in the bud; it would stop criticism as it reared its head, and it would gather all the power to the supreme party and the party leaders, rising like stately pinnacles above their vast bureaucracies of civil servants, no longer servants and no longer civil.

The image of the party leaders as "stately pinnacles" was a pleasing one. The remark about civil servants was also gratifying to the ear, gaining power from the repetition and reversal of words, neatly reinforcing the idea of reversal of the function of officials, from servants to tyrants. The power of the "Gestapo" phrase came in part from the fact that it brought the alleged threat to freedom alive in a way that an abstract word such as "fascism" was unlikely to achieve. But the comment's infelicity was obvious, and this was actually increased by Churchill's use of the qualifying phrase "no doubt very humanely directed in the first instance." This was clearly an attempt to further convey that socialists did not intend to introduce a horrific state of affairs but would be forced to do so over time by the logic of their own doctrines. However, the idea of a "humanely directed" Gestapo was self-contradictory. If a socialist government's methods of control were initially 
humane-no matter what they might later descend into-they could not at that point be considered equivalent to those of the Gestapo. And if they were equivalent to those of the Gestapo, then they could not be considered humane. After all, the Gestapo's history was not that of a well-intentioned organization gone wrong.

Churchill went on to anticipate a potential objection (a rhetorical maneuver known as "prolepsis"). To do this, he addressed the listener directly, putting into his or her mouth a rhetorical question: "But, you will say, look at what has been done in the war. Have not many of those evils which you have depicted been the constant companions of our daily life?" To this he replied that it was true that quasi-socialist conditions had been a necessity during the emergency conditions of war. "We all submit to being ordered about to save our country," he said. "But when the war is over and the imminent danger to our existence is removed, we cast off these shackles and burdens which we imposed upon ourselves in times of dire and mortal peril, and quit the gloomy caverns of war and march out into the breezy fields, where the sun is shining and where all may walk joyfully in its warm and golden rays." The metaphor of emergence from the dark was reminiscent of his speech of 18 June 1940, in which he had spoken of the possibility that if Hitler were defeated, the world could "move forward into broad, sunlit uplands." It was a rare moment of relief in a broadcast that contained few light spots.

Churchill's assault on Labour was not yet complete. He turned to the party's plans to nationalize the Bank of England. Once a socialist government began "monkeying with the credit of Britain," no one's nest egg would be safe, he argued. ${ }^{73}$ This was an echo of the charge leveled in 1931 that the return of Labour would endanger savings held in the Post Office Bank. Churchill drew attention to Greenwood's remark in February 1943 that pounds, shillings, and pence had become "meaningless symbols." (Greenwood's point had been that true wealth derived from the real economy rather than from finance. $)^{74}$ Churchill said that "all this 'meaningless symbol' talk is very dangerous" and that it would lead to the debauchment of the currency. His own government stood for maintaining the value of the pound, he said, "and we would rather place upon all classes, rich and poor alike, the heaviest burden of taxation they can bear than slide into the delirium of inflation." Here was another echo of 1931 and the talk then of "equality of sacrifice" across classes. Warning that electing him offered "no guarantee of lush and easy times ahead," Churchill also gave a minor reprise of his "blood, toil, tears and sweat" speech of 13 May 1940. Under him, pounds, shillings, and pence would not become meaningless symbols, he promised: "On the contrary, our resolve will be that what has been earned by sweat, toil and skill or saved by selfdenial shall command the power to buy the products of peace at an equal value in sweat, toil and skill." He then justified having engaged in a long disquisition on socialism versus individualism, on the grounds that he had been forced into it. "That is because for the first time the challenge has been made, in all formality,

\footnotetext{
${ }^{73}$ In fact, Churchill did not oppose the nationalization of the bank when the new government legislated for this in 1946. Hugh Dalton, High Tide and After: Memoirs, 1945-1960 (London, 1962), 45.

${ }^{74}$ Greenwood, Speech to the House of Commons, 16 February 1943, Parliamentary Debates, Commons, 5th ser., vol. 386 (1942-43), col. 1624.
} 
'Socialism versus the rest." This, of course, was the theme that he had earlier identified in his letter to Croft.

The concluding section of the broadcast referred to the problems of demobilization and to Britain's weakened economic position. "What a mad thing it would be to slash across this whole great business of resettlement and reorganization with these inflaming controversies of Socialistic agitation!" Churchill said. He contrasted the "vast revolutionary change" supposedly represented by Labour's plans with his own proposals for "practical and immediate action." His peroration further emphasized the importance of practicality, combining the military themes of marching and returning warriors with a cozy vision of domesticity: "On with the forward march! Leave these Socialist dreamers to their Utopias or their nightmares. Let us be content to do the heavy job that is right on top of us. And let us make sure that the cottage home to which the warrior will return is blessed with modest but solid prosperity, well fenced and guarded against misfortune, and that Britons remain free to plan their lives for themselves and for those they love." The reference to "the cottage home" might have seemed misplaced in a country so heavily urbanized as Britain. Admittedly, Baldwin, whose career had ended only a few years beforehand, had made highly successful use of rural imagery; this was part of his ethical appeal, that of a plain man of the people, who could be trusted because he was not "clever." 75 But if the high-living and mentally frenetic Churchill was aiming to emulate this homespun technique, he did not do so successfully. Ross McKibbin has argued persuasively that in the interwar years the Conservative Party had successfully appealed to the Liberal nonconformist base by toning down its own language: "Many of its older, rhetorically aggressive traditions were abandoned in favour of a more reticent and sanctimonious style," which Baldwin personified. ${ }^{76}$ In spite of the quasi-Baldwinian "National" elements of the Gestapo speech, it was also blatantly aggressive. Arguably, Churchill was returning to the platform techniques he had learned in his youth, having assimilated only partially the lessons that Baldwin's example could teach.

Indeed, it is tempting to draw parallels between the Gestapo speech and late nineteenth-century popular Toryism of the kind described by Jon Lawrence. The working man's right to live his life free from interference by busybodies (especially in regard to alcohol) had then been a classic theme. However, we may also note some important differences. For as long as the Liberal Party remained strong, Conservatives assaulted its principles head on, arguing that its commitment to laissez-faire meant that only Tories could be trusted to deliver legislation in the interests of the workers. ${ }^{77}$ But in 1945, with the Liberal Party on its last legs, Churchill chose (as in the 1920s) to reach out to its supporters by claiming to embrace its values. He presented Conservatism and Liberalism as allies, not antagonists, in the face of the greater socialist threat. Paradoxically, this putative alliance in defense of "freedom" was made easier by the fact that Liberalism itself had moved some way from laissez-faire.

\footnotetext{
${ }^{75}$ See Williamson, Stanley Baldwin.

${ }^{76}$ Ross McKibbin, Classes and Cultures: England, 1918-1951 (Oxford, 1998), 96.

${ }^{77}$ Jon Lawrence, Speaking for the People: Party, Language and Popular Politics in England, 1867-1914 (Cambridge, 1998), esp. 106-7.
} 
The day after the broadcast, Churchill was greeted in the House of Commons by ironic cries of "Where's the Gestapo?"78 Some Conservative MPs were buoyed up by the speech. "Chips" Channon thought that "the Labour boys seem very depressed and dejected by Winston's trouncing" and noted that his own colleagues were "cock-a-hoop." Nevertheless, he thought their optimism was excessive. ${ }^{79}$ Cuthbert Headlam's opinion was that the speech "rather overdid the business I thought, so far as sensible people are concerned-but then there are few sensible people and the rank and file of the party may welcome a fighting speech from the leader." ${ }^{80}$ Journalists quickly began to report that some Tories were unhappy, although the Manchester Guardian's parliamentary correspondent suggested that Churchill's own good mood at Question Time indicated that he felt the broadcast had gone well. ${ }^{81}$ Press comment tended to divide on predictable lines, but the contrast in coverage provided by two left-wing papers is interesting. In an astute move, the Daily Herald reported Churchill's speech quite fully, interspersed with rebuttals offered by Herbert Morrison. The paper took Morrison's “crazy broadcast" remark for its main headline. ${ }^{82}$ The Daily Mirror, for its part, ran "Jap Spy Pigeons to Face Falcon Terror" as its chief story, with "Churchill Claims He Is Leading National Govt." relegated further down the page. Although it reported accurately the gist of his attack on socialism, the Gestapo comment itself was omitted. ${ }^{83}$ By any standards, this was shoddy journalism: either the writer had failed to spot the most newsworthy quotation or he or she deliberately held it back in the (as it turned out, false) belief that it was damaging to Labour.

Attlee's reply to Churchill was broadcast on the evening of 5 June. Several parts of it were in the form of direct rejoinders to the prime minister, notably the masterful opening passage:

When I listened to the Prime Minister's speech last night, in which he gave such a travesty of the policy of the Labour Party, I realized at once what was his object. He wanted the electors to understand how great was the difference between Winston Churchill, the great leader in war of a united nation, and Mr. Churchill, the party leader of the Conservatives. He feared lest those who had accepted his leadership in war might be tempted out of gratitude to follow him further. I thank him for having disillusioned them so thoroughly. The voice we heard last night was that of $\mathrm{Mr}$. Churchill, but the mind was that of Lord Beaverbrook. ${ }^{84}$

Here, Attlee skillfully combined the sarcastic suggestion that Churchill was deliberately undermining his own electoral chances with the powerful idea that there were two Winston Churchills. This was a trope that was to be taken up by other Labour speakers and, in the aftermath of the election, was represented visually in

\footnotetext{
78 "Was Worth 50 Seats to Labour," Daily Herald, 6 June 1945.

${ }^{79}$ Robert Rhodes James, ed., "Chips": The Diaries of Sir Henry Channon (1967; repr., London, 1993), 408 (entry for 5 June 1945).

${ }^{80}$ Stuart Ball, ed., Parliament and Politics in the Age of Churchill and Attlee: The Headlam Diaries, 1935-1951 (Cambridge, 1999), 462.

81 "Tory Doubts on Premier's Broadcast," Manchester Guardian, 6 June 1945.

82 "Churchill's Crazy Broadcast," Daily Herald, 5 June 1945.

83 "Churchill Claims He Is Leading National Govt.," Daily Mirror, 5 June 1945.

84 "Labour Case for Socialism," The Times, 6 June 1945.
} 
a famous cartoon by David Low. ${ }^{85}$ As Mary Soames has put it, praiseworthy warleader Churchill was contrasted with reprehensible party-leader Churchill, the latter portrayed as "irresponsible, out of touch with ordinary people, subject to the malign influence of Lord Beaverbrook, and not to be trusted in peacetime." Beaverbrook was a press magnate with a reputation as an evil genius. Attlee's suggestion that he had inspired Churchill's broadcast resonated strongly. The Daily Herald, reporting Attlee's speech, gave a visual representation of it at the top of its front page: "The Voice Was the Voice of [arrow pointing to photo of Churchill] but the Mind Was the Mind of [arrow pointing to photo of Beaverbrook]." ${ }^{\prime 7}$ Attlee had managed to undermine Churchill's apparently impregnable character-based claims, not via a direct assault but by exploiting the perceived negative character of somebody else.

Attlee was similarly adroit when he dealt directly with the Gestapo passage. He pointed out that Scandinavian countries as well as Australia and New Zealand had elected left-wing governments without dreadful consequences. ${ }^{88} \mathrm{He}$ added: "I shall not waste time on this theoretical stuff, which seems to me to be a secondhand version of the academic views of an Austrian professor-Friedrich August von Hayek - who is very popular just now with the Conservative Party." 89 This suggests that he may well have read the copy of The Road to Serfdom that Assheton had sent him. (Morrison had definitely read it, as had key Labour intellectuals.) ${ }^{90}$ Richard Cockett has observed that Attlee "subtly" emphasized "Hayek's foreign origins to persuade his listeners that Hayek was nothing more than a mad foreign professor who did not understand the English way of doing things." "91 This is true enough. Attlee, though, was himself contending with claims, such as those made by Assheton, that socialism's allegedly Germanic origins rendered it suspicious. Churchill's own reference to "this continental conception of human society called Socialism" had been very much in that vein. ${ }^{92}$ Attlee's broadcast provoked some press interest in Hayek (although the coverage of him was more limited than Cockett implies)..$^{93}$ "I wrote the book essentially to persuade the Socialists to act wisely, but I do not seem to have succeeded in that," he told the Daily Telegraph.

\footnotetext{
${ }^{85}$ Published on 31 July 1945 in the Evening Standard, the cartoon was called "The Two Churchills." It showed one Churchill, "the leader of humanity," sitting on a pedestal, commiserating with the other one, "the party leader," down below. "Cheer up!" the former tells the latter. "They will forget you but they will remember me always."

${ }^{86}$ Soames, Clementine Churchill, 545.

${ }^{87}$ Daily Herald, 6 June 1945.

${ }^{88}$ This theme was taken up in the Labour-supporting press. See, e.g., Maurice Kitching, "New Zealand Is Insulted," Reynolds News, 10 June 1945; and F. A. Cooper, "Where Labour Has Ruled for 27 Years and They've Never Seen a Gestapo Man," Reynolds News, 24 June 1945. Cooper was writing about Queensland, of which he was premier.

89 "Labour Case for Socialism," The Times, 6 June 1945.

${ }^{90}$ For Morrison, see "The Road to Serfdom," Daily Express, 6 June 1945; for the broader Labour reaction to the book, see Richard Toye, The Labour Party and the Planned Economy, 1931-1951 (London, 2003), 136-38.

${ }^{91}$ Cockett, Thinking The Unthinkable, 5.

${ }^{92}$ Speech of 4 June 1945.

${ }^{93}$ Cockett suggests that "the press descended" on Hayek and that he gained "star-status" in the campaign along with Harold Laski (Thinking the Unthinkable, 96). Yet only one paper provided any in-depth coverage of Hayek's ideas (Frederick Cook, "This Is the Road to Serfdom," Evening Standard, 6 June 1945); otherwise, there were only a few snippets.
} 
"I have no connection with the Conservative Party." ${ }^{94}$ He told Beaverbrook's Daily Express, however, that he was delighted "if any party has the wisdom to profit" from The Road to Serfdom, which implies that he did not disapprove of Churchill's broadcast at the time..$^{95}$

In the final section of his speech, Attlee contested Churchill's claim that his government was a "National" one. Not only was the government a Conservative government, he argued, but the Conservative Party was "a class Party" that had rarely drawn any MPs from "the ranks of the wage-earners" and continued to represent "property and privilege." Moreover, "The Labour Party is, in fact, the one party which most nearly reflects in its representation and composition all the main streams which flow into the great river of our national life." ${ }^{96}$ This was a neat attempt to reclaim the "national" label from the Tories, and it fell in with a long-established effort to present Labour's patriotic credentials to the electorate, which was also reflected in the Labour manifesto "Let Us Face the Future." did, though, give the Express the chance to caption its account of his talk with the insinuating headline "The National Socialists." 98

Many individuals left records of their reactions to the exchange between Churchill and Attlee. A considerable number of these people were MPs or other elite figures. For example, Churchill's good friend, the Liberal politician Violet Bonham Carter, wrote in her diary on 4 June, "Have just heard W's broadcast which really does lay it on a bit thick!" Two days later, she wrote, "Attlee gave a good \& dignified \& reasoned \& constructive reply to Winston." "99 After listening to Attlee, Leo Amery's son Julian, himself a Conservative candidate, "had considerable searchings of heart" regarding his political allegiance. ${ }^{100}$ Margaret Thatcher recalled in her memoirs: "I vividly remember sitting in the student common room in Somerville [College, Oxford] listening to Churchill's famous (or notorious) election broadcast . . . and thinking, 'he's gone too far.' However logically unassailable the connection between socialism and coercion was, in our present circumstances the line would not be credible."101 George Bernard Shaw was unusual in providing an extended, albeit slightly eccentric, analysis of Churchill's rhetoric. He did not hesitate to brand the speech a fiasco but was more sympathetic in his treatment than were many others on the Left. "He was as good as ever on his own ground of romantic militarism," Shaw argued. He added: "As a pre-Marxian glory merchant he has been a first-rate entertainer all through, and has kept up the spirit of the nation quite splendidly. Unhappily, when he was nearly through his broadcast

\footnotetext{
94 "Prof. Von Hayek," Daily Telegraph and Morning Post, 6 June 1945.

95 "The Road to Serfdom," Daily Express, 6 June 1945.

96 "Labour Case for Socialism," The Times, 6 June 1945.

${ }^{97}$ See Paul Ward, "Preparing for the People's War: The Left and Patriotism in the 1930s," Labour History Review 67, no. 2 (August 2002): 171-85.

98 "The National Socialists," Daily Express, 6 June 1945.

${ }^{99}$ Mark Pottle, ed., Champion Redoubtable: The Diaries and Letters of Violet Bonham Carter, 1914-1945 (London, 1998), 350-51.

${ }^{100}$ Barnes and Nicholson, Empire at Bay, 1046.

${ }^{101}$ Margaret Thatcher, The Path to Power (London, 1995), 45.
} 
after a prosperous voyage, his party pilots queered his compass and misled him on to the rocks of up-to-date matter-of-fact unromantic policy, of which he knows much less than nothing. In a moment the eloquent patriotic orator became a raving Anarchist tub-thumper, modern only in his trick of calling policemen Gestapos." 102 Shaw painted the speech as absurd rather than-as might have been expected in the immediate aftermath of Belsen-obscene. In this he was at one with Churchill's other left-wing critics. They did not describe the broadcast as a disgusting insult to the victims of fascism. Rather, they depicted it as "crazy"cheap and semicomic, sad and undignified — but, at the same time, as predictable given the Conservatives' previous record of election "scares." Some adopted an in-sorrow-not-in-anger approach, in which Churchill was pitied rather than excoriated. ${ }^{103}$ And, as Attlee's broadcast showed, ridicule was a highly effective weapon. A cartoon in the Daily Herald on 6 June 1945 provides another telling example of this. It depicted a soldier on crutches contemplating a poster, with the legend "Only Conservatives are National-Churchill." The man mused: "So it seems I haven't been fighting for my country after all."

The reactions of ordinary voters to the speech were broadly negative. The speech was listened to by a high proportion of voters; according to Asa Briggs, Churchill's four election broadcasts reached an average of 49 percent of the potential total audience. ${ }^{104}$ It is not known how many read it in the papers the next day; there was doubtless a considerable degree of overlap between listeners and readers. Although the latter experienced it in a mediated form, there is no evidence to suggest that reactions differed greatly depending on whether the speech was heard or read. Some interesting reactions were captured through the work of the research organization Mass-Observation (MO). ${ }^{105}$ Mass-Observation had pioneered qualitative political opinion research in Britain. ${ }^{106}$ According to MO's report on the election, "It would be difficult to exaggerate the disappointment and genuine distress aroused by this speech." The report reproduced a large number of observations from citizens, many along the lines of this: "The whole speech seems to have been in bad taste. No one but the veriest baby in politics would believe his assumption that the Labour Leaders are potential Gestapo officials." Attlee's contribution was often viewed positively - for example, this comment: "It was a fair speech and very truthful. He didn't use any election stunting." But the existence of these negative reactions should not be allowed to obscure that of more positive ones. Mass-Observation's report noted that the question "Which speeches on the wireless or in the papers did you like best?" found more people preferring Churchill's speech to that of any other single speaker. However, unlike those who preferred other speakers, these respondents tended not to give concrete reasons for their preference. They offered reasons such as "I've always listened to all his speeches" and "He is a great man, and we should listen to him." The report argued that "This type of reply indicates a simple loyalty that transcends criticism;

\footnotetext{
${ }^{102}$ George Bernard Shaw, "Churchill's Fiasco," Forward, 16 June 1945.

${ }^{103}$ See Morrison's comments in "Churchill's Crazy Broadcast," Daily Herald, 5 June 1945.

${ }^{104}$ Briggs, History of Broadcasting, 627.

105 There is need for considerable caution when using MO material; the selection of the comments may have been influenced by the political persuasions of the observers, who tended to be on the Left.

${ }^{106}$ Joe Moran, "Mass-Observation, Market Research, and the Birth of the Focus Group, 1937-1997," Journal of British Studies 47, no. 4 (October 2008): 827-51.
} 
and it was the conflict between this feeling and the rational disapproval and disagreement that his actual statements aroused which formed one of the keynotes of the election."107 This remark may well be thought to reveal the report's proLabour bias. It should also be noted that Labour's Gallup poll lead declined from 16 percent on 28 May to 9 percent on 18 June, although we should hesitate to attribute this to the impact of Churchill's speech, given that 69 percent of those interviewed by Gallup thought it "bad." 108

Presumably, voters were not just influenced by one speech but were also affected by the rest of the campaign, hence the importance of the ways in which other politicians took up the Gestapo theme. The Nuffield survey of the 1945 election noted that many of Churchill's supporters followed him in attacking "'Socialism' in the abstract rather than the published programme of the Labour party. In so doing, they nearly always went on to blacken Socialists as anti-democrats and friends of Fascism." The authors provided examples, including that of Harold Balfour, who said (on 15 June) that "the Socialist State of Cripps is to be the same as the Fascist state of the blackshirts." ${ }^{109}$ At an even more extreme level, Howard Leicester, National candidate at Bethnal Green South-West, prepared a circular that said: "A Socialist State needs a Gestapo and Concentration Camps. Think this over and remember Belsen." 110 The so-called "Laski scare"-the allegation that the Labour Party National Executive Committee, under its chairman Harold Laski, would dictate policy to an Attlee government-was an attempt to extend the Gestapo theme. Some Tory candidates referred to "Gauleiter Laski." 111 Others, though, were uncomfortable with Churchill's broadcast. After polling, the Newbury Weekly News praised the victorious local Tory, Anthony Hurd, for his refusal to stress "the Laski and Gestapo stunts" and attributed his win in part to the fact that he had campaigned "on more dignified and positive lines." 112 David Renton, who successfully fought for election in Huntingdonshire as a National Liberal, recalled that Churchill's Gestapo speech “didn't go down well. I made a joke of it in Huntingdonshire and found that other people made a joke of it too. Rather giving the impression that he'd intended it as a bit of a joke."113

Historians tend to suggest that, as Steven Fielding puts it, "Hostility to blatant partisanship explains the response to Churchill's infamous first radio speech of the campaign." 114 The implication is that Labour did not engage in similar tactics. It is true that Attlee refrained from repeating the comparison he had made when the coalition broke up. Others were far less restrained, however, taking Churchill's broadcast as a license to reply in kind. The Independent Labour Party's New Leader highlighted a story of state brutality against strikers when Churchill was home

\footnotetext{
107 "Report on the General Election, June-July 1945," File Report 2270A, October 1945, MassObservation archive, University of Sussex.

${ }^{108}$ Paul Addison, The Road to 1945 (London, 1975), 266; Steven Fielding, "What Did 'The People' Want? The Meaning of the 1945 General Election," Historical Journal 35, no. 3 (September 1992): $623-39$, at 632.

${ }^{109}$ R. B. McCallum and Alison Readman, The British General Election of 1945 (London, 1947), 144.

110 "He's the Silliest Candidate of the Election," Daily Mirror, 28 June 1945.

${ }^{111}$ McCallum and Readman, British General Election, 148.

${ }^{112}$ Douglas Hurd, Memoirs (London, 2004), 48.

${ }^{113}$ Quoted in Austin Mitchell, Election '45: Reflections on the Revolution in Britain (London, 1995), 69.

${ }^{114}$ Fielding, "What Did 'The People' Want?" 631.
} 
secretary before World War I. After describing the battery of civilians by police and soldiers, it revealed that this was "not Germany under Hitler" but "Britain under Winston Churchill!" 115 Emrys Hughes declared in Forward that if Churchill "had been born in Germany he would have been a Nazi." Admittedly, the British plutocracy had not yet needed a Hitler to maintain its interests, "But if ever the time did come when Big Business and Vested Interests found it necessary to dispense with their pretended devotion to democracy, we have no illusions as to who would be running the Gestapo."116 Toward the end of the campaign, he published a further article under the headline "Fuhrer Churchill!" in which he criticized the Conservative campaign's focus on the prime minister: "This attempt to create and exploit mass emotion, to idolise one man, and to make people think he is the only possible leader, is the British Tory attempt to imitate the Fuhrer worship of the Nazis." 117 Michael Foot, journalist and candidate for Plymouth Devonport, also referred to Churchill, perhaps half in jest, as the Tory "Fuehrer."118 This idea was certainly a potential source of humor, as in the limerick quoted at the start of this article.

Some such examples were fairly trivial. ${ }^{119}$ But many of the attacks were serious and cannot be dismissed as simply the work of the lunatic fringe or of obscure candidates. Senior Labour figures were happy to associate the Conservatives with fascism. Cripps, speaking in Glasgow, found it sinister that there was no mention of the word "Conservative" in Churchill's manifesto: "In Cumberland I saw someone was running as a 'Churchill candidate'. We seem to be getting nearer and nearer the Fuhrer idea." 120 A. V. Alexander, former first lord of the admiralty, declared that before the war, "Under Tory rule there were millions of wives whose housekeeping money consisted of a bare unemployment allowance under the Gestapo of the means test." "21 In one of Labour's official election broadcasts, Philip Noel-Baker, MP, argued, on the basis of the 1935 Anglo-German Naval Treaty, that "the Tories helped the Axis." 122 The Liberals also joined in. "The Conservative Party claim the definite right to govern apparently in perpetuity," claimed Lord Samuel, echoing remarks made previously by Herbert Morrison. "That is the principle of Nazism and Fascism." 123 To draw attention to these remarks is not to claim that they were precisely equivalent to Churchill's language. Opposition politicians did not tend to make the explicit claim that the return of a Conservative government would lead literally to totalitarianism. The crucial point is that Tories and their press supporters would have found it much easier to attack the claims

\footnotetext{
${ }^{115}$ Jon Evans, "Churchill-Enemy of the Workers!" New Leader, 16 June 1945. On Churchill's record as home secretary in relation to the Gestapo speech, see also the comparatively mild but nonetheless critical remarks of J. Chuter Ede, MP, quoted in "Election Letters," Daily Herald, 6 June 1945.

${ }^{116}$ Hughes, "'Gestapo Will Get You."”

${ }^{117}$ Emrys Hughes, "Fuhrer Churchill!" Forward, 30 June 1945.

${ }^{118}$ Michael Foot, "Why This 'National' Label Is a Shameful Fraud," Daily Herald, 19 June 1945.

${ }^{119}$ See "Rejoinders to Premier's Broadcast," Manchester Guardian, 6 June 1945; and "Tory Gestapo Put Gag on Leading Scientists,' Reynolds News, 17 June 1945. For examples relating to Tory MPs' alleged fascist sympathies, see Kelly, "'Ghost of Neville Chamberlain," 21.

120 "Cripps Answers Churchill," Forward, 16 June 1945.

121 "Tories and Mr. Churchill," Manchester Guardian, 12 June 1945.

122 "Axis Aid by Tories," Sunday Pictorial, 17 June 1945.

123 "Liberals Are Rallying in the West," News Chronicle, 9 June 1945. For Morrison's comments, see "Churchill's Crazy Broadcast," Daily Herald, 5 June 1945.
} 
they did make as extreme had not Churchill spiked his own side's guns with his reference to the Gestapo.

And what of Churchill himself? A draft for his second election broadcast (given on 13 June) included the following remark: "I am glad the word 'Gestapo' stung, because it will show a lot of harmless and worthy people the way they are going, and where they will finish up if they are not stopped in good time while the nation remains free." ${ }^{124}$ When it came to the point, he did not say this, but he did renew the charge that under socialism "all effective and healthy opposition and the natural change of parties in office from time to time would necessarily come to an end, and a political police would be required to enforce an absolute and permanent system upon the nation." "25 Speaking in South London at the very end of the campaign, he explicitly repeated the Gestapo claim, in words very close to those he had used in his broadcast. When a heckler objected, Churchill told him: "I see an ugly look on your face. It looks just like what a Gestapo would resemble."126

In the interval between polling day and the announcement of the results, Churchill and Attlee traveled together to Potsdam. During the conference, Churchill introduced Stalin to Lord Cherwell ("the Prof"), his scientific and statistical adviser, for the first time. According to Roy Harrod's memoir of Cherwell, the prime minister "had no ready formula for describing the Prof. He explained that he was a man who had been advising him about a balanced use of our resources for the war effort, drawing his attention to shortfalls, and generally keeping his eye on the whole scene of government, to inform him if anything was amiss; in fact he had acted as a kind of Gestapo for him. 'Oh!' said Stalin immediately, 'I thought it was only Mr. Attlee who had a Gestapo.'”127

It is a myth that during the election Churchill and the Conservatives engaged in a form of "blatant partisanship" that the opposition responsibly eschewed. ${ }^{128}$ In pointing this out, we need not descend to the level of Beaverbrook's Evening Standard, which, responding to early criticisms of the Gestapo speech, drew attention to Attlee's earlier remarks and asked, "Well, who began it?"129 And we certainly should not go as far Colm Brogan, a polemicist admired by Margaret Thatcher, who accused Labour of using tactics during the election that would have put Goebbels to shame. ${ }^{130}$ Rather, we need to consider why the myth arosewhich it did very quickly-in order to understand more clearly the nature of Churchill's rhetorical transgression. Why was he unable to get away with saying that Labour would have to rely on some form of Gestapo, when his opponents

\footnotetext{
${ }^{124}$ Draft of broadcast of 13 June 1945, Churchill Papers, CHAR 9/208B, fol. 106.

${ }^{125}$ Broadcast of 13 June 1945.

126 "Crowds Cheer and Jeer," Manchester Guardian, 5 July 1945.

${ }^{127}$ R .F. Harrod, The Prof: A Personal Memoir of Lord Cherwell (London, 1959), 255.

${ }^{128}$ The Nuffield survey did concede that "the opposition papers had almost a monopoly of abuse," but the target of this remark was the press, not politicians. McCallum and Readman, British General Election, 190.

129 "You Are Warned," Evening Standard, 5 June 1945.

${ }^{130}$ Colm Brogan, Our New Masters (London, 1947), 5; Thatcher, Path to Power, 51-52.
} 
took little heat for suggesting that the Conservatives accepted fascist principles? What unwritten rule had he broken?

One possibility is that comparing one's opponents to Nazis was generally allowable, but not for prime ministers or potential prime ministers. Having initially goaded Churchill with his comments on the referendum idea, Attlee surely did well to drop this line of criticism, creating a contrast between his own calm demeanor and his opponent's apparently hysterical tone. It may also be that Attlee's colleagues would all have done well to follow—as many actually did-his "commonsense" method of attack rather than alleging that Churchill was the Tory equivalent of Hitler. All the same, it is not clear that the line of attack adopted by Churchill was necessarily infra dig for a prime minister. During the $1964 \mathrm{elec}-$ tion-admittedly at some remove from the horrors of Belsen-Sir Alec DouglasHome drew parallels between the activities of Labour hecklers and the past thuggery of the Nazis. ${ }^{131}$ In 1976, James Callaghan accused Conservative leader Margaret Thatcher of being "rather Goebbelistic" in her descriptions of Labour's economic record. This caused no great storm; in fact, the Labour Party put out a leaflet to advertise the remark. ${ }^{132}$ Moreover, Churchill's critics at the time and since did not, in the main, accuse him of being "un-prime-ministerial" but rather of having done something inconsistent with the position of "national leader." "133

Innumerable commentators on the Gestapo speech have suggested that, having held that position, he threw it away at a stroke. ("Mr. Churchill last night put off national leadership and became a party chieftain of the old-fashioned type," claimed the News Chronicle.) ${ }^{134}$ They all appeared to assume that this "national leader" status was a tremendous advantage for him and that only a character defect, mental spasm, or the sinister influence of Beaverbrook and Bracken could have led him to jeopardize it. Churchill himself clearly valued that status but at the same time must have appreciated its fragility; the slightest misstep could open him to the charge that he was failing to live up to it. This explains the lengths to which he went in the broadcast to shore up his "National" credentials, a strategy that, on the surface, made sense given the pool of former Liberal support that stood to be captured. ${ }^{135}$ Yet his attempt to distance himself from Conservatives by identifying himself as "National" backfired. This was because the Conservatives were themselves associated with the "National" label, always portrayed by Labour as a fraud, a claim much more easily pressed after the events of 1940. Attlee's achievement in his reply was to manipulate the various senses of "national" to Churchill's

\footnotetext{
${ }^{131}$ Lawrence, Electing Our Masters, 210.

${ }^{132}$ The leaflet, along with a copy of Callaghan's remark in Hansard (9 November 1976) can be found in the Thatcher Papers, THCR $2 / 7 / 1 / 37$, CAC.

${ }^{133}$ However, Morrison did suggest that Churchill's comments came ill from one holding "the high office of Prime Minister." “Churchill's Crazy Broadcast,” Daily Herald, 5 June 1945.

134 “Opening Salvo," News Chronicle, 5 June 1945.

${ }^{135}$ The Liberals put up only 306 candidates (there were 640 constituencies). A Gallup poll conducted after the campaign closed found that "about 23 per cent. of the total electorate would have voted for the Liberal Party, given the opportunity" ("58 Per Cent. Opposed Election," News Chronicle, 26 July 1945). It remains unclear whether the Liberal involvement in the election damaged Labour or the Tories most. See Bentley B. Gilbert, “Third Parties and Voters' Decisions: The Liberals and the General Election of 1945," Journal of British Studies 11, no. 2 (May 1972): 131-41; Walter L. Arnstein, “The Liberals and the General Election of 1945': A Skeptical Note," Journal of British Studies 14, no. 2 (May 1975): 120-26.
} 
disadvantage. In his account, Churchill had been the great leader of the united nation - and had, with his broadcast, stopped being so. The addition of a few independents and domesticated Liberals did not make his caretaker government National, a point the demise of National Labour reinforced. In contrast to the sectionalism of the Conservatives, Labour was the true national party, capable of transcending class interests in a way that Churchill could not. Churchill's apparently winning card turned out to be dud.

This is not to say that Churchill played his hand well. His appeal to individualism was intelligible in the context of an appeal to Liberals, especially given the Liberal Party's own wartime swing to the left, but the Gestapo remark was an unforced error. He may have intended it as a broader, politico-philosophical point, but it is scarcely surprising that it was seen as a personal attack on the Labour politicians with whom he had recently worked closely. The standard explanations for the mistake are not without merit. He was indeed physically and mentally exhausted after five years as prime minister at war. "I am worried about this damned election," he told his doctor midway through the campaign. "I have no message for them now." 136 This contributed to a failure that was artistic as much as political. On 22 June, Vita Sackville-West, instinctively Conservative but not much interested in politics, wrote to her husband, the National Labour MP Harold Nicolson: "You know I have an admiration for Winston amounting to idolatry, so I am dreadfully distressed by the badness of his broadcast Election speeches. What has gone wrong with him? They are confused, woolly, unconstructive and so wordy that it is impossible to pick out any concrete impression from them. If I were a wobbler, they would tip me over to the other side." ${ }^{137}$ Arguably, though, his rhetorical collapse was the product of his political predicament rather than the primary cause of it. The role of "national leader" in which he found himself imprisoned was widely perceived to preclude various kinds of conduct in which, as a party leader at election time, it was hard to avoid indulging. ${ }^{138}$ When protesting his wife's suggestion that he should retire at the end of the war to avoid having to lead one section of the nation against the other, he liked to say that he was not yet ready "to be put on a pedestal." ${ }^{139}$ His tragedy in 1945 was that he was already on the pedestal and, if he wanted to continue in politics, he would inevitably be pilloried for stepping down from it.

\footnotetext{
${ }^{136}$ Moran, Winston Churchill, 254.

${ }^{137}$ Vita Sackville-West to Harold Nicolson, 22 June 1945, in Harold Nicolson: Diaries and Letters, 1939-1945, ed. Nigel Nicolson (London, 1967), 472.

${ }^{138}$ A point made effectively in "The Unfinished Task," Spectator, 8 June 1945.

${ }^{139}$ Soames, Clementine Churchill, 544.
} 